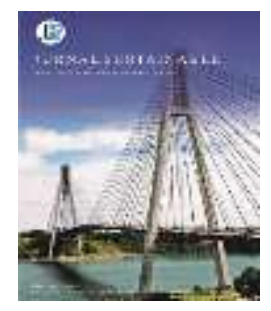

Jurnal Sustainable: Jurnal Hasil Penelitian dan Industri Terapan

Vol. 07, No. 02, hal. 86-94, Oktober 2018

Jurnal Sustainable: Jurnal Hasil Penelitian

dan Industri Terapan

ISSN 2615-6334 (Online)

ISSN 2087-5347 (Print)

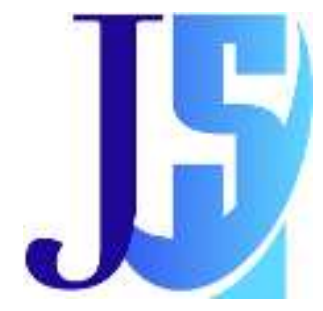

\title{
Design Thinking sebagai Bridge of Innovation Perguruan Tinggi dan Industri di Jurusan Teknik Elektro Universitas Maritim Raja Ali Haji (UMRAH)
}

\author{
Deny Nusyirwan*, \\ Jurusan Teknik Elektro, Fakultas Teknik, Universitas Maritim Raja Ali Haji \\ Jl. Politeknik Senggarang, Tanjungpinang 29115 \\ * Corresponding Author : denynusyirwan@umrah.ac.id
}

\begin{abstract}
The universities as the part of a foundation of the innovations see the importance of equipping the engineering background graduates with knowledge of innovation, which is indispensable in the industrial world. Therefore, universities and industries strive to synergize to create the appropriate teaching methodes and systems without eliminating the characteristics and benchmarks of these universities which will then become the brand of the collaboration to compete with other universities in the competition of graduates in the job seek. Department of Electrical Engineering at the Faculty of Engineering Universitas Maritim Raja Ali Haji (TE FT UMRAH) has seen the importance of this matter and has applied the design thinking as a bridge of innovation between universities and industry in initiating the various innovations so it is expected that the graduates of TE FT UMRAH will be able to accelerate the innovations in the industry

Keywords - Design Thinking, Collaboration, Innovation
\end{abstract}

Intisari-Perguruan tinggi sebagai bagian dari sebuah foundation of innovation, melihat akan pentingnya membekali lulusan dengan berlatar belakang teknik dengan pengetahuan mengenai inovasi, dimana hal ini sangat diperlukan di dunia industri. Oleh sebab itu, perguruan tinggi dan industri berusaha bersinergi untuk menyusun pola dan sistem pengajaran yang sesuai dengan tanpa menghilangkan ciri khas dan benchmark dari perguruan tinggi tersebut yang selanjutnya akan dapat menjadi brand of collaboration untuk bersaing dengan perguruan tinggi lainnya didalam persaingan lulusan di dunia kerja. Jurusan Teknik Elektro di Fakultas Teknik Universitas Maritim Raja Ali Haji (TE FT UMRAH) sudah melihat akan pentingnya hal ini dan sudah menerapkan pola pengetahuan design thinking sebagai bridge of innovation antara perguruan tinggi dengan industri didalam menginisiasi berbagai macam inovasi sehingga kedepannya sangat diharapkan bahwa lulusan TE FT UMRAH akan dapat langsung berakselerasi didalam melakukan inovasi di industri.

Kata kunci-Perancangan Cerdas, Koloborasi, Inovasi. 


\section{Pendahuluan}

Negara Singapura telah menunjukkan keseriusan akan pentingnya design thinking dalam meningkatkan kemampuan inovasi industri dalam meningkat daya saing perusahaan dan mempersiapkan lulusan universitas yang siap berinovasi, hal ini dibuktikan dengan telah dibentuknya sebuah lembaga bernama Design Singapore Council (DSC) dibawah kementrian informasi dan komunikasi singapura pada tahun 2003 dengan tujuan untuk membantu perguruan tinggi dan industri di singapura dalam sektor inovasi dan desain (design and innovation), selain itu singapura juga melihat akan pentingnya pengetahuan design thinking ini didalam mendesain sebuah produk yang sukses dengan memanfaatkan pengetahuan yang luas didalam mendesain (science behind great product design), oleh sebab itu Design Singapore Council (DSC) saat ini bermitra dengan beberapa perguruan tinggi di Singapura dalam melaksanakan pelatihan design thinking untuk karyawan di perusahaan (company) ataupun mahasiswa yang sedang belajar di program studi/jurusan pada perguruan tinggi unggulan di Singapura. Bahkan di beberapa perguruan tinggi tersebut juga sudah mengintegrasikan design thinking ke dalam kurikulum, diantaranya adalah Program Studi Innovation \& Design Centric Programme (iDCP) di National University of Singapore (NUS), Singapore University of Technology and Design (SUTD), Nanyang Polytechnic (NYP) school of engineering, INSEAD Business School.

Demikian juga perguruan tinggi di amerika, Franklin W. Olin College of Engineering, telah menempatkan design thinking menjadi bagian yang penting didalam metode pembelajaran User-Oriented Collaborative Design, dimana mahasiswa sebagai seorang calon engineer juga dilatih untuk berpikir secara kreatif dan luas (broad and creative thinking) dan inovatif sehingga dapat menghasilkan sebuah karya yang merupakan solusi untuk merubah pola hidup masyarakat menjadi lebih baik (transform the way people live).
Selain di perguruan tinggi, hingga saat ini beberapa perusahaan juga masih mempergunakan design thinking didalam proses inovasi, adalah google, motorolla, Deutsche Bank dan World Bank. Adapun contoh manfaat dari design thinking ini adalah didalam melakukan perancangan fasilitas (design facilities), desain produk dan pemasaran (branding and design product) dan pengembangan teknologi (technology development).

Dalam tulisan ini, akan diberikan penjelasan mengenai pengertian design thinking dan selanjutnya akan diterangkan pola pembelajaran design thinking di beberapa perguruan tinggi luar negeri, selanjutnya akan di tutup dengan pola pembelajaran design thnking yang sudah dimulai dan masih berjalan di jurusan teknik elektro UMRAH.

\section{Metode DeSign thinking (DT) DI PERGURUAN TINGGI}

Design Thinking (DT), istilah yang sudah mulai memasyarakat (familiar) di kalangan rekayasawan (engineer) dan juga di lingkungan perguruan tinggi [1].

Istilah Design Thinking ini telah diperkenalkan oleh David Kelly, pendiri IDEO dan Design School pada Stanford University yang menyampaikan bahwa manusia adalah sebagai element utama didalam mendesain [2], hal ini dimaksudkan bahwa seorang mahasiswa yang akan dipersiapkan sebagai innovator unggul didalam proses untuk menghasilkan sebuah inovasi, diminta untuk melibatkan langsung pengguna (user) sejak awal proses observasi untuk dapat menemukan, memahami permasalahan dan memberikan solusi yang selanjutnya dapat meningkat taraf hidup masyarakat.
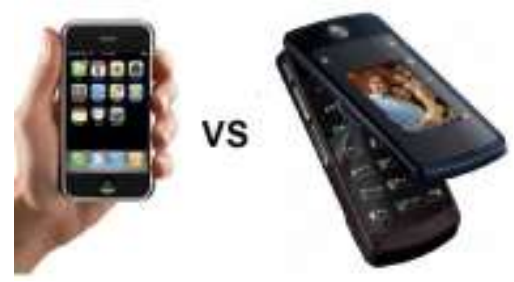

Gambar 1. Pemanfaatan Design Thinking di dalam pengembangan teknologi dan inovasi [2]. 
DT meminta mahasiswa untuk mampu berpikir secara luas dan menangkap semua permasalahan ditemukan dengan tanpa melakukan pengelompokan terlebih dahulu (divergence).

Adapun semua usulan disampaikan dengan cara melalui sebuah proses yang dinamakan brainstorming dengan maksud memberikan banyak solusi terhadap yang dihadapi, dalam tahapan ini dimana kuantitas dari solusi yang disampaikan lebih diprioritaskan dari kualitas.

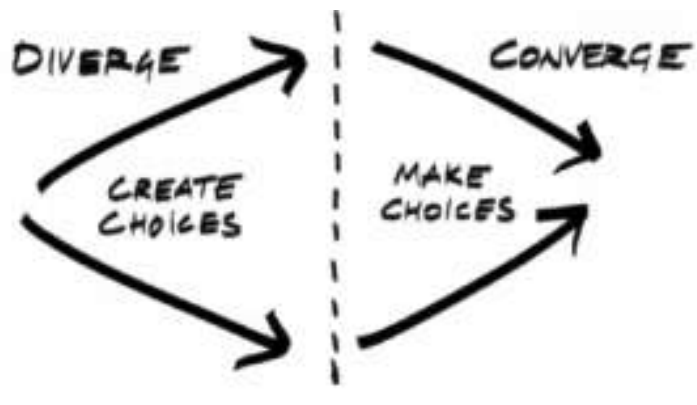

Gambar 2. Berpikir secara luas dan selanjutnya menentukan pilihan [2].

Tahapan selanjutnya adalah convergence, dimana mahasiswa akan di minta untuk mampu memberikan pilihan terhadap usulan yang sudah disampaikan. Pilihan dilakukan dengan melalui sebuah proses pengelompokan dan feasibility.

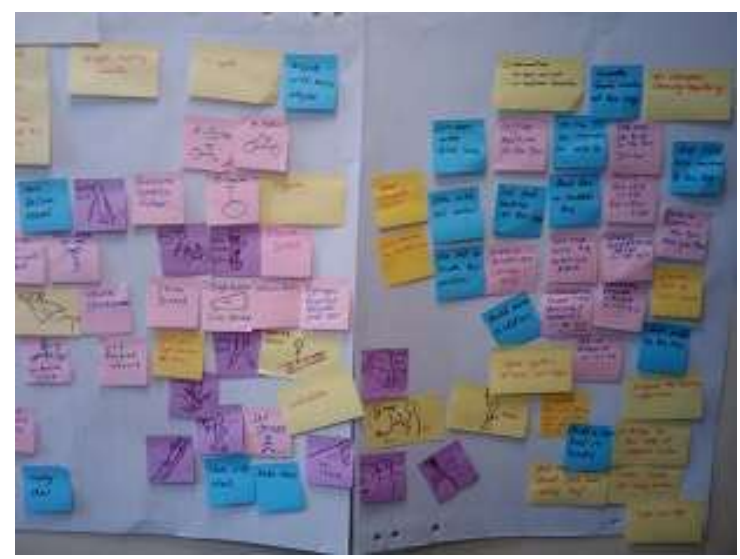

Gambar 3. proses pengelompokan setelah dilakukan brainstorming

Adapun beberapa perbedaan berinovasi dengan memanfaatkan DT dan berinovasi secara tadisional adalah sebagai berikut :
A. DT melakukan perancangan bersama pengguna

Seperti yang sudah disampaikan sebelumnya bahwa DT menjadikan manusia (human) sebagai key element didalam mendesain sebauh inovasi, dimana dalam tahapan awal DT dimulai dengan metode observasi dan interaksi langsung, dimana seorang inovator dan desainer langsung berinteraksi dengan pengguna (user) dengan demikian akan mendapatkan data-data secara langsung dan lengkap, sehingga solusi yang diberikan akan dapat sesuai kepada masyarakat.

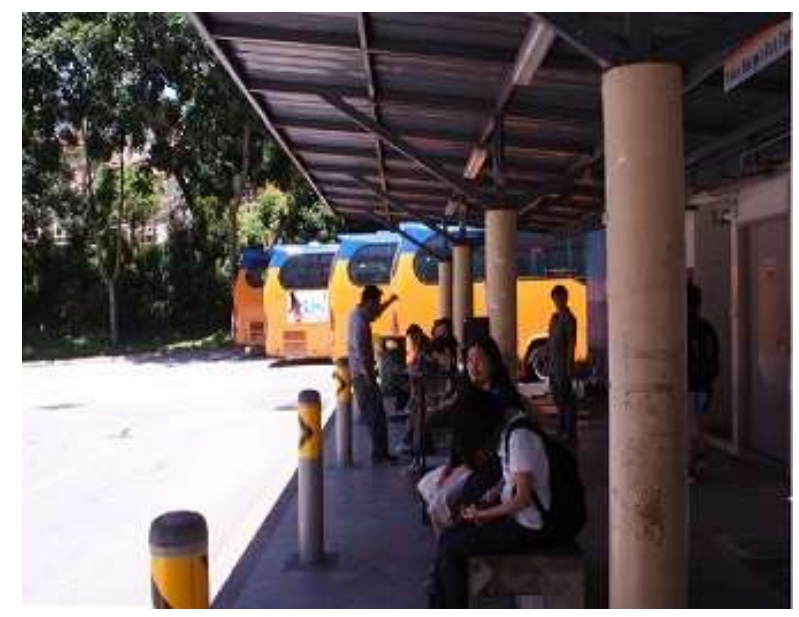

Gambar 4. Observasi dan interaksi langsung dengan calon pengguna

Pengguna akan terlibat langsung didalam perancangan dengan melakukan pengujian prototipe awal (low resolution prototype), yang selanjutnya dengan feedback yang didapatkan akan dilakukan proses perbaikan, yang selanjutnya di uji kembali oleh pengguna. Hal ini disebut sebagai proses iterasi didalam DT [3].

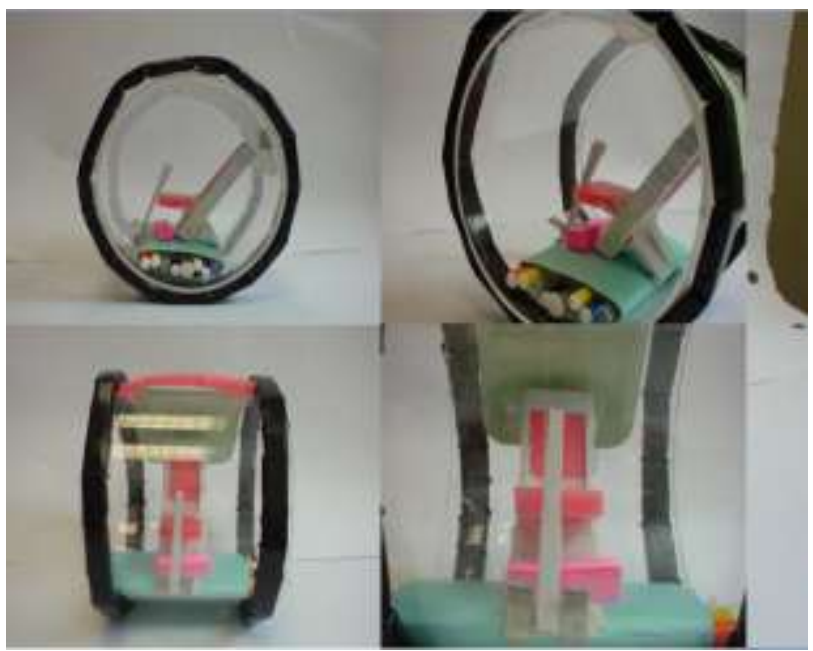

Gambar 5. Prototipe awal (low resolution prototype) 
Adapun didalam proses perancangan secara tradisional, hasil (output) dari inovasi dan desain adalah merupakan dari proses design for, adapun kekurangan didalam perancangan ini adalah, kesuksesan yang masih belum pasti karena tidak melibatkan pengguna didalam proses perancangan.

\section{B. DT lebih banyak mendengarkan dari pada sering bertanya}

Observasi yang dilakukan bertujuan untuk mendapatkan informasi sebanyak mungkin yang selanjutnya akan dipergunakan untuk menghasilkan solusi terhadap masyarakat di suatu daerah. Dalam observasi dengan menerapkan metode DT ini, dapat dilakukan dengan pengamatan secara langsung dengan tanpa mengintervensi kegiatan keseharian, ataupun memberikan pertanyaan-pertanyaan (questioner) yang sudah disiapkan terlebih dahulunya. Pola pertanyaan akan lebih diarahkan pada pertanyaan-pertanyaan yang bersifat terbuka (open question), sehingga ruang lingkup informasi yang didapatkan akan lebih luas dan tidak terbatas dibandingkan dengan pertanyaan yang bersifat tertutup (close question) yang diterapkan oleh pola tradisionil. Selain itu, mendengarkan secara serius dan memperhatikan apa yang disampaikan juga akan lebih memotivasi orang yang sedang kita ajak bicara untuk memberikan jawaban berupa uraian-uraian yang panjang [4].

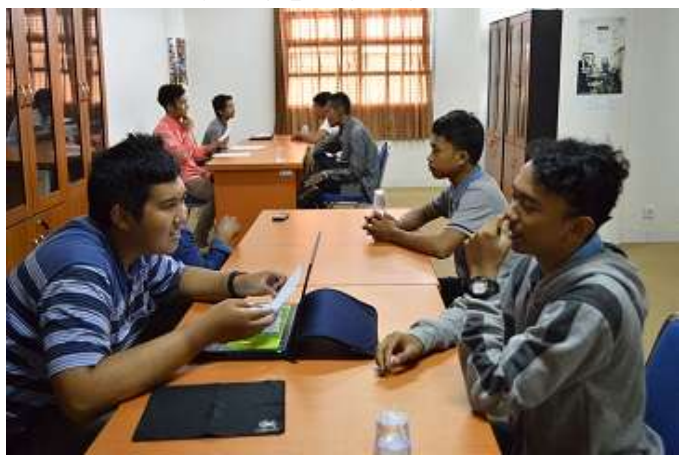

Gambar 6. Mendengarkan secara serius dan memperhatikan apa yang disampaikan.

Hal ini tentu bertolak belakang dengan metode pengumpulan data secara tradisionil, dimana interwiever lebih banyak bertanya dari pada menjelaskan.

\section{DT menggunaan purwarupa didalam penyampaian ide.}

Pemanfaatan Low Resolution Prototype (LRP) didalam proses perancangan teknik (engineering design process) adalah merupakan bagian dari design thinking dan sangatlah mempengaruhi tingkat keberhasilan dari sebuah inovasi, oleh sebab itu, adalah merupakan sebuah landasan yang sangat baik apabila di setiap perguruan tinggi sudah membekali mahasiswa dengan latar belakang teknik (engineering) untuk mampu memahami pemanfaatan low resolution prototype secara maksimal.

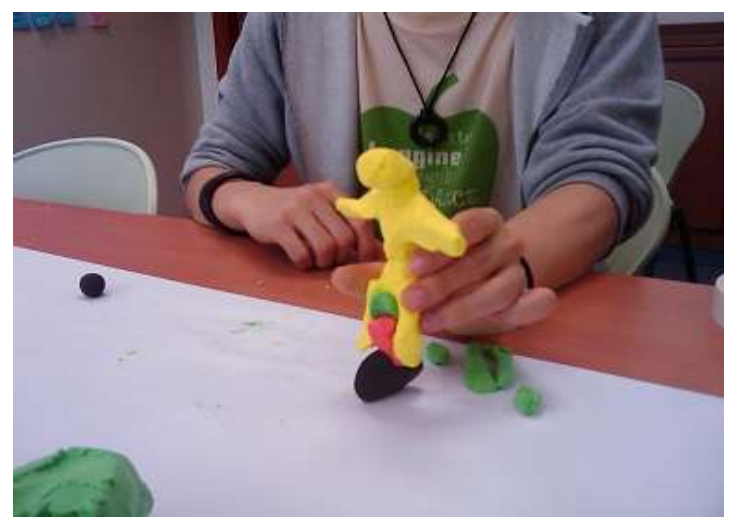

Gambar 7. Menggunakan purwarupa (prototype) didalam penyampaian ide.

\section{Berbagi}

Berbagi didalam penyampaian ide untuk dapat mendorong rekan lainnya agar dapat menyampaikan ide-ide yang merupakan solusi untuk permasalahan di masyarakat. Bentuk sharing ini dapat berupa purwarupa sederhana yang disampaikan fungsi nya dengan menjelaskan kepada rekan-rekan satu kelompok, kemudian akan dianalisa bersama untuk kelebihan dan kekurangannya.

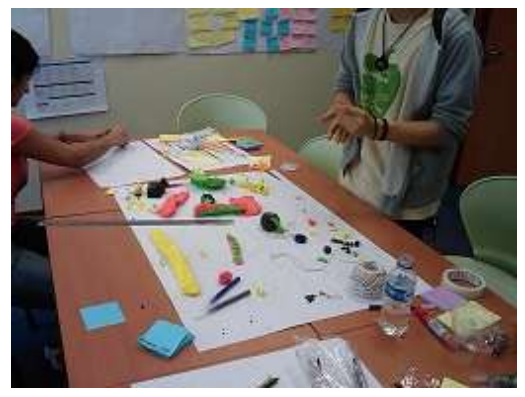

Gambar 8. Berbagi (sharing) melalui pemanfaatan purwarupa. 
Beberapa aturan yang sangat bermanfaat didalam berbagi untuk dapat memotivasi rekanrekan di kelompok, diantaranya yaitu :

- menghindari penilaian secara langsung dan membantah ide yang sedang disampaikan.

- mendorong adanya ide-ide yang luar biasa/aneh.

- berpikir seperti anak kecil, dimana tidak takut akan kesalahan.

- mengedepankan jumlah ide yang disampaikan, kuantitas daripada kualitas.

- mempertahankan semua pembicaraan dan diskusi serta ide yang disampaikan tetap pada topic, tidak keluar dari ketetapan awal.

- tidak ada yang berbicara secara bersamaan, dimana saling memberikan kesempatan untuk menyelesaikan pendapatnya terlebih dahulu.

\section{E. DT merupakan kombinasi dari analytical dan intuitive thinking}

DT adalah merupakan perpaduan yang produktif antara analytical thinking dan intuitive thinking, dimana keduanya sangat diperlukan untuk menghasilkan sebuah inovasi.

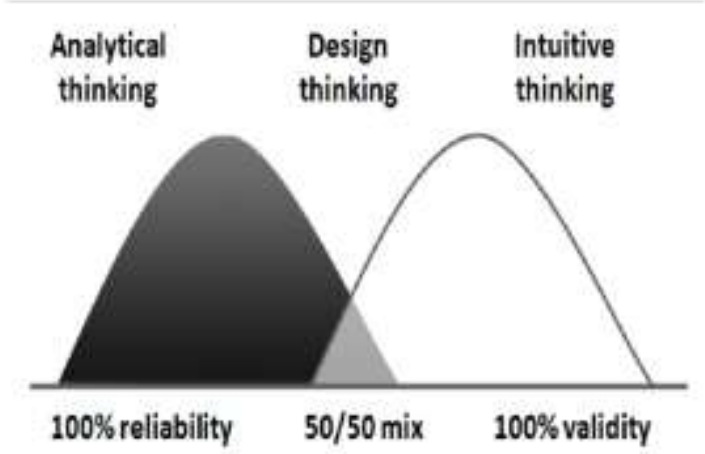

Gambar 9. Perpaduan yang produktif antara analytical thinking dan intuitive thinking.

Perusahaan ataupun industri yang masih mengedepankan pola inovasi dengan cara tradisional cenderung untuk mempergunakan analytical thinking, hal ini dapat dipahami namun akan dapat menanggung resiko untuk strategi kedepannya, karena inovasi yang dihasilkan adalah merupakan extrapolasi dari data-data yang sudah didapatkan sebelumnya, hal ini hanya akan dapat berfungsi jika perusahaan berpendapat bahwa kondisi pada masa depan tidak jauh beda dengan sebelumnya
[5]. Namun jika hanya mempergunakan intuitive thinking, maka tidak akan mendapatkan keuntungan dalam bentuk data-data sebelumnya yang akan dipergunakan untuk menentukan prediksi selanjutnya. Oleh sebab itu diperlukan kombinasi keduanya [6].

\section{Pembahasan}

Jurusan Teknik Elektro UMRAH telah memeperkenalkan Design Thinking kepada mahasiswa sejak di semester awal perkuliahan sebagai bagian yang tidak terlepaskan dari proses pembelajaran mata kuliah-mata kuliah teknik, dimana DT merupakan satu faktor penting didalam perancangan, beberapa projek yang telah diajukan (proposed) mahasiswa dalam perkuliahan dan telah melalui DT adalah sebagai berikut :

A. Monitoring pembebanan berlebihan pada rumah tangga (overload monitoring).

Perkembagan di suatu daerah akan diikuti dengan pertumbuhan daerah pemukiman penduduk dan semakin bertambahnya perumahan , dalam proses awal observasi, mahasiswa telah melakukan pengamatan secara langsung pada perumahan yang berlokasi di kota tanjungpinang, dimulai dengan mengunjungi rumah dengan luas bangunan $128 \mathrm{~m}^{2}$ (rumah type 128 ), $80 \mathrm{~m}^{2}$ (rumah type 80 ) dan $36 \mathrm{~m}^{2}$ (type 36).

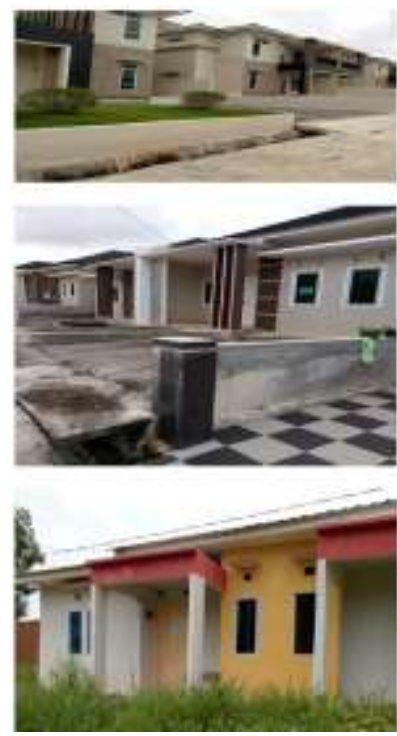

Gambar 10. Observasi pada perumahan type 128, type 80 dan type 36 
Dari hasil observasi dan wawancara yang telah dilakukan dimana hal ini adalah merupakan proses divergence pada DT, didapatkan permasalahan-permasalah yang kerap muncul pada perumahan, yaitu pembebanan listrik yang berlebihan, peralatan elektronik tersambar petir, PLN yang hidup mati dan loose breaker pada trafo. Dalam tahapan design thinking selanjutnya yaitu convergence, permasalahan akan di titik beratkan pada pembebanan yang berlebihan akibat pemakaian kebutuhan listrik di rumah tangga.

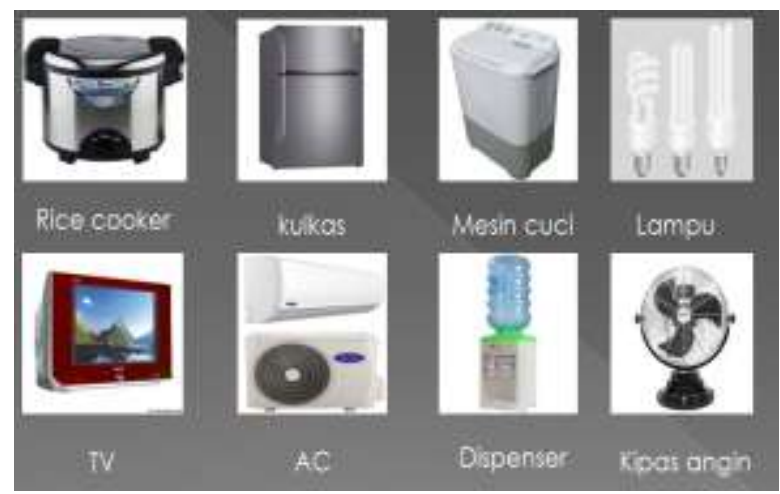

Gambar 11. Peralatan listrik dan elektronik yang pada umumnya terdapat di rumah tangga

Untuk mendapatkan informasi lanjut terkait pembebanan listrik di rumah, dilakukan pengamatan secara langsung di lapangan terhadap peralatan listrik dan elektronik yang pada umumnya terdapat di rumah tangga seperti alat pemasak nasi, lemari pendingin, pendingin, lampu penerangan, televisi, penyejuk udara, kipas angin dan bahkan dispenser.

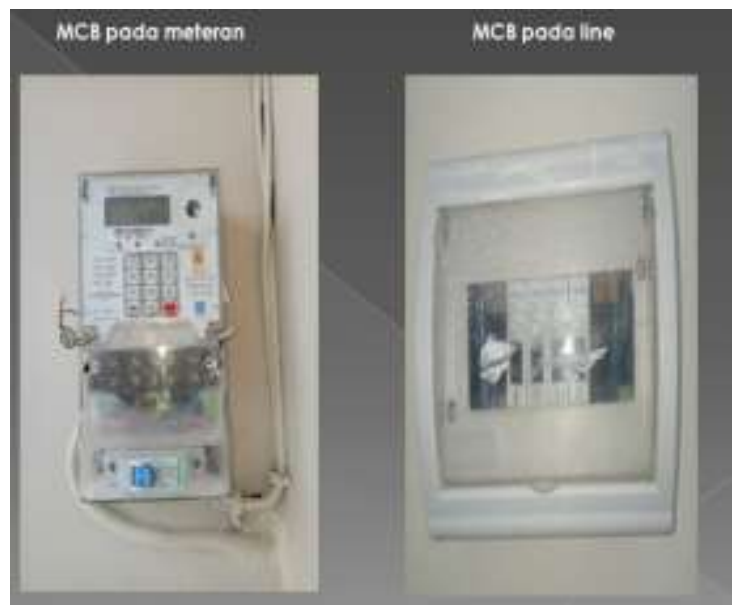

Gambar 12. Main Contact Breaker (MCB) yang terdapat pada dalam rumah (MCB LINE)
Langkah selanjutnya didalam observasi adalah mengamati Main Contact Breaker (MCB) yang terdapat pada dalam rumah (MCB LINE), dan telah didapati bahwa rumah type 128 memiliki jumlah MCB lebih banyak dari rumah type 80 dan 36 . Dari hasil pengamatan ini menyatakan bahwa semakin kecil type rumah di sebuah perumahan yang dibangun oleh pengembang (developer) maka akan semakin sedikit juga MCB yang di pergunakan sebagai pengamanan di dalam rumah tersebut.

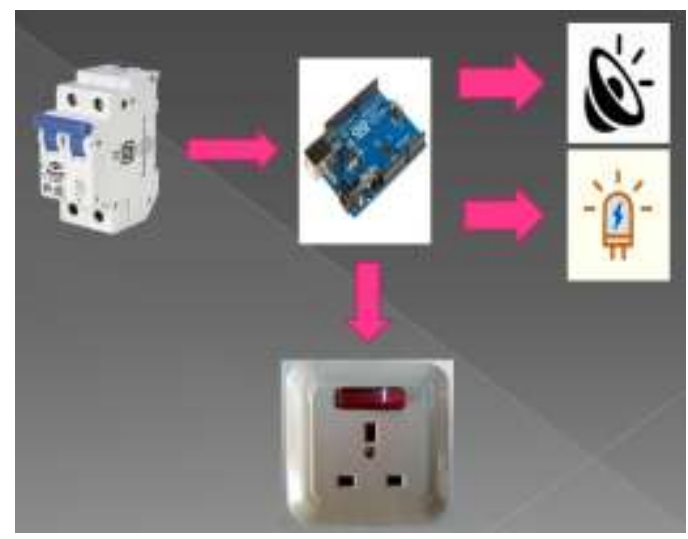

Gambar 13. Peringatan berupa bunyi (sound) dan kedipan lampu pada alat deteksi apabila kebutuhan listrik didalam rumah sudah mendekati kebuthan maksimal.

Dari hasil observasi, wawancara dan design thinking, maka diusulkan sebuah inovasi berupa sebuah alat yang dapat mendeteksi pembebanan yang berlebihan di rumah tangga.

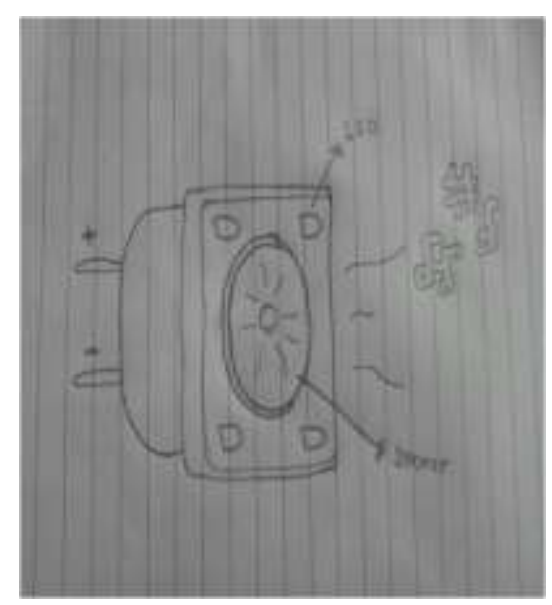

Gambar 14. Low Resolution Prototype

Adapun peringatan tersebut berupa bunyi (sound) dan kedipan lampu pada alat deteksi apabila kebutuhan listrik didalam rumah sudah mendekati kebuthan maksimal yang di izinkan, 
hal ini untuk menghindari terjadinya putusnya arus listrik akibat pembebanan yang berlebihan overload .

\section{B. Monitoring lampu jalan dan penerangan umum di perumahan}

Meningkatnya perekonomian di suatau daerah, maka akan di ikuti juga dengan meningkatnya aktifitas masyarakat di daerah tersebut, dimana yang awalnya aktifitas berahir di sore hari, maka dengan ini dapat hingga malam hari. Selain infrastruktur jalan yang dapat mendukung, pemerintah juga telah membantu menyediakan lampu penerangan untuk di jalan ataupun di perumahan agar supaya warga nyaman didalam mempergunakan lampu jalan di malam hari dan menghindari terjadi kecelakaan akibat penerangan yang tidak cukup. Dari hasil observasi awal etnografi pada salah satu lokasi di tanjungpinang, yang berupa pengamatan langsung telah di temukan lampu penerangan umum yang tidak berfungsi.

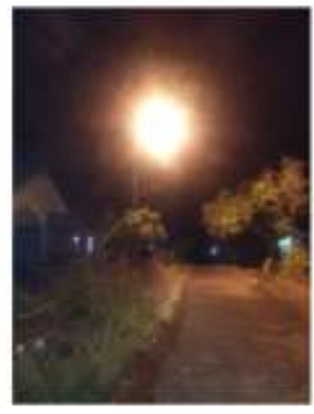

Jalan ganet perumahan hangtuah 4 Tanjungpinang Kepulawan RIAU

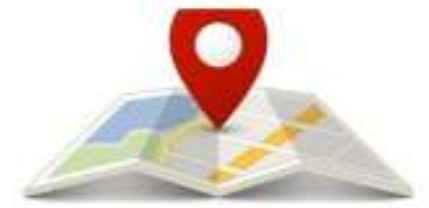

Gambar 15. Observasi awal etnografi pada salah satu lokasi di tanjungpinang

Untuk mendapatkan infomasi terkait permasalahan tersebut, maka telah dilakukan wawancara langsung dengan perwakilan masyarakat dan didapati bahwa sering terdapat lampu yang mati namun warga tidak mengetahui lokasinya, kurangnya pengetahuan warga terkait perawatan lampu jalan dan dalam proses perbaikan memerlukan waktu.

Dari hasil brainstorming yang di lakukan maka diperlukan sebuah aplikasi yang dapat mendeteksi lokasi (localize) lampu penerangan jalan yang mati dan menginformasikan kesalahan (error) yang terjadi.
BRAINSTROMING

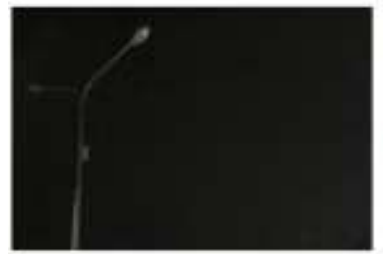

Pengontrol lampu jalan sebagai sebuah solusi untuk masyarakat apar tidak terpanggu aktifitas penerangan pada malam han
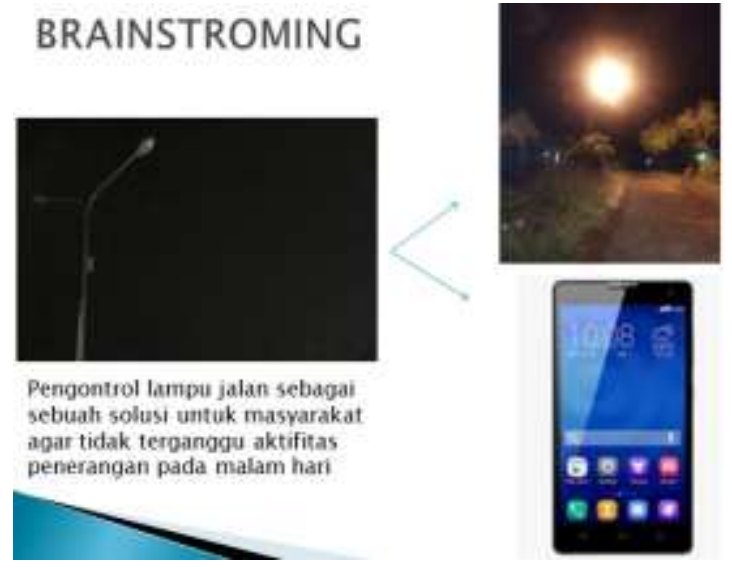

Gambar 16. Brainstorming

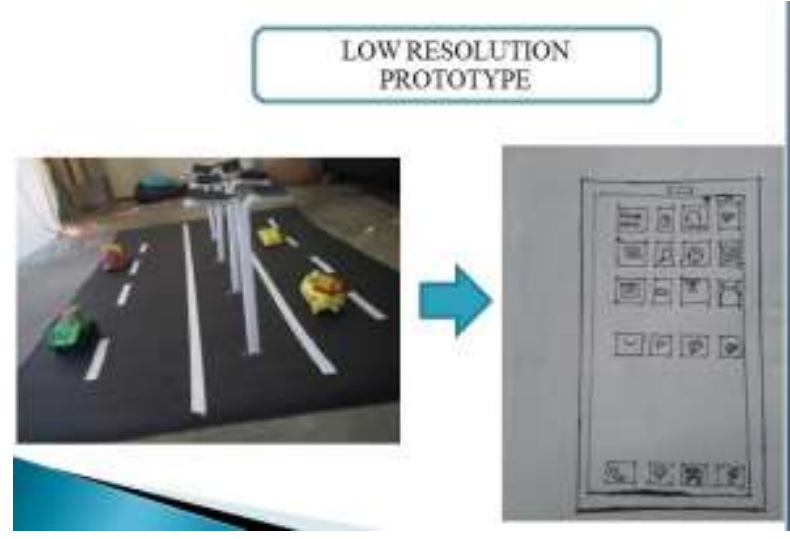

Gambar 17. Low Resolution Prototype sebagai hasil dari Design Thinking

\section{Menaikkan kelapa dari sungai}

Daerah Riau, Sei Guntung sangat terkenal dengan penghasil kelapa, dimana kondisi daerahnya juga yang sangat mendukung untuk pengembangan perkebunan kelapa.

\section{Observasi di Masyarakat}

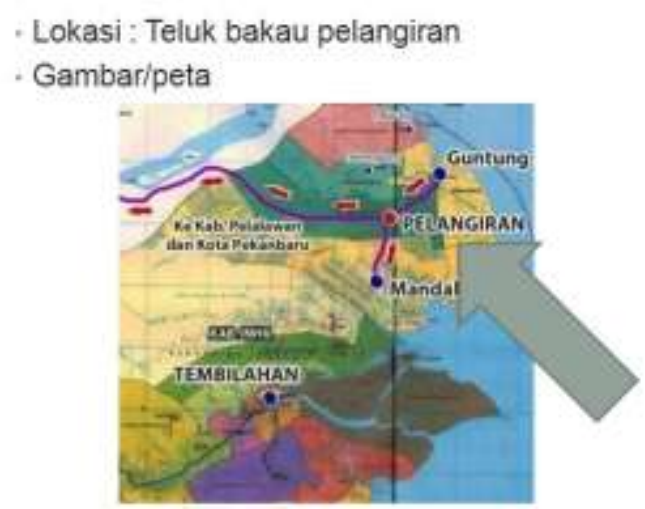

Gambar 18. Observasi di masyarakat teluk bakau pelangiran 
Namun sayangnya masih terdapat beberapa permasalahan yang masih ditemukan dari hasil observasi langsung di lapangan yang telah dilakukan oleh mahasiswa, yaitu sulitnya pompong pengangkut kelapa untuk masuk ke sungai, pekerja kelapa kurang, jarak pengangkutan kelapa yang jauh dan sulitnya menaikkan kelapa dari sungai.

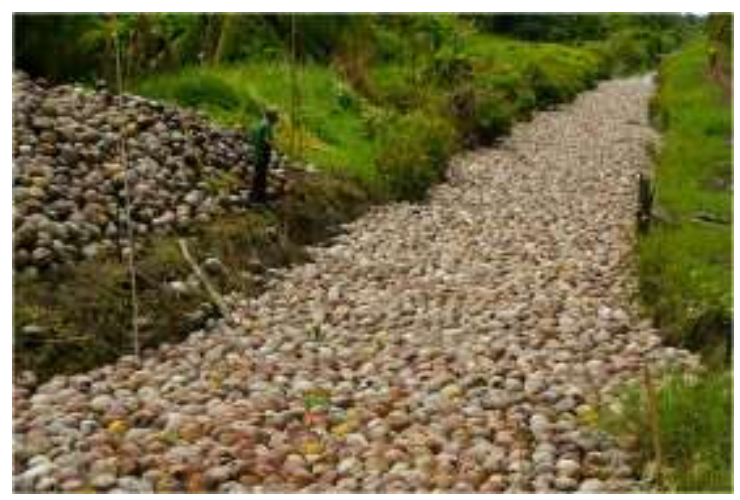

Gambar 19. Kelapa di sungai yang siap untuk diangkut ke darat.

Hingga saat ini, untuk menaikkan kelapa dari sungai masyarakat masih menggunakan tombak, melempar dengan tangan, jejaring paku dan katrol yang masih dilakukan menggunakan tenaga manusia.

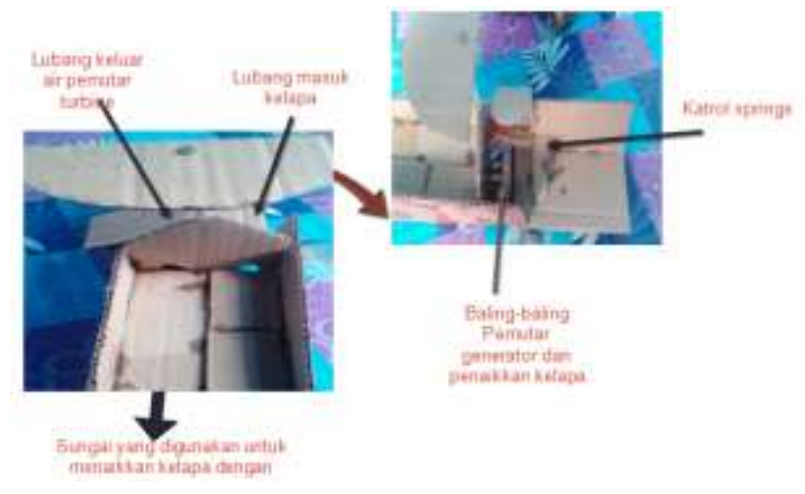

Gambar 20. Low Resolution Prototype sebagai hasil dari Design Thinking

Dari hasil proses design thinking yang telah dilakukan maka diusulkan sebuah solusi yaitu dengan merancang sebuah baling yang berfungsi dengan menggunakan tenaga air, dimana kelapa yang ada disungai akan di bending dan selanjutnya tenaga air akan memutar baling/kipas yang telah dirancang sesuai kebutuhan.

\section{KESIMPULAN}

Design Thinking sebagai jembatan inovasi dengan industri, telah dibuktikan oleh jurusan teknik elektro FT UMRAH sebagai sebuah elemen penting didalam menciptakan lulusan yang siap di dunia kerja. Mahasiswa diminta untuk melalui sebuah proses yang merupakan tahapan didalam menciptakan sebuah inovasi, bentuk kegiatan seperti etnografi, wawancara dan brainstorming adalah merupakan hal-hal yang sangat diperlukan namun sangat sulit untuk bisa dilaksanakan di industri karena kesibukan untuk melakukan kegiatan produksi. Oleh sebab itu, industri juga menginginkan agar perguruan tinggi untuk dapat berusaha melengkapi dengan menerapkan pola pembelajaran design thinking di beberapa mata kuliah terkait teknik, dimana akan dapat melatih mahasiswa untuk memberikan solusi yang tepat terhadap permasalahan yang ada di masyarakat dengan bersandarkan pada analytical dan intuitive thinking yang seimbang dan siap untuk langsung terjun ke industri.

Dalam DT ini, mahasiswa telah diajarkan bagaimana untuk menemukan permasalahan dan mendapatkan data-data yang diperlukan sebagai masukan untuk mendapatkan solusi yang tepat.

\section{UCAPAN TERIMA KASIH}

Terima kasih kepada Ketua Jurusan dan rekan di jurusan Teknik Elektro yang telah memberikan kesempatan melakukan penelitian mengenai Design Thinking sebagai bridge of innovation perguruan tinggi dan industri di Jurusan Teknik Elektro.

\section{REFERENSI}

[1] Harvard Business Review, Tim Brown, Design Thinking, Juni 2008.

[2] Manoa Innovation Center \& Iolani School Student Center, an introduction to Design Thinking, 18 Juli 2011.

[3] Harvard Business School Case 609-066, Thomke, Stefan H., and Barbara Feinberg, Design Thinking and Innovation at Apple, January 2009. (Revised May 2012.) 
[

4] Springer, Hasso Plattner, Christoph Meinel, Larry Leifer, Design Thinking, Mei 2010

[5] Creelman Research, Roger Martin, Design Thinking, 2009 Vol. 2.9
[6] Asian Development Bank Knowledge Solutions, Olivier Serrat, Design Thinking, Maret 2012. 